\title{
Seroprevalence Study of Brucella Infection in and around Rewa District, India
}

\author{
Vandana Gupta $^{1 *}$, Namrata Singh ${ }^{2}$, Sanjay Kumar Shukla ${ }^{2}$, Varsha Sharma ${ }^{1}$, \\ Anju Nayak ${ }^{1}$, Joycee Jogi ${ }^{1}$, Poonam Shakya ${ }^{1}$ and Ajay Rai ${ }^{1}$ \\ ${ }^{1}$ Department of Veterinary Microbiology, College of Veterinary Science and \\ A.H., Jabalpur, M.P., India \\ ${ }^{2}$ Department of Veterinary Microbiology, College of Veterinary Science and \\ A.H., Anand, Gujarat, India \\ *Corresponding author
}

\section{A B S T R A C T}

\begin{tabular}{|l|}
\hline K e y w o r d s \\
$\begin{array}{l}\text { Antibrucella } \\
\text { antibodies, } \\
\text { Brucellosis, c- ELISA, } \\
\text { RBPT, Seroprevalence }\end{array}$ \\
\hline Article Info \\
\hline $\begin{array}{l}\text { Accepted: } \\
\text { 29 September } 2017 \\
\text { Available Online: } \\
\text { 10 October } 2017\end{array}$ \\
\hline
\end{tabular}

Keywords

Antibrucella antibodies,

Brucellosis, c- ELISA,

Article Info

Accepted:

Available Online:

10 October 2017
The present work was conducted to study the seroprevalence of Brucella infection amongst the cattle population in and around Rewa district (Madhya Pradesh). Seroprevalence study was conducted using Rose Bengal Plate Test and SVANOVIR Brucella Antibody c-ELISA kit. C-ELISA is OIE referred gold standard test for detecting Brucella antibodies. Around 50 serum samples were screened for the presence of Brucella antibody using both Rose bengal plate test (RBPT), and Competitive Enzyme Linked Immunosorbent assay (c- ELISA) kit. Out of 50 samples tested with Rose Bengal Plate Test and c-ELISA, 42\% and 20\% were detected to be positive respectively. Rose Bengal Plate Test was not sensitive enough to detect weak positive sample, which were detected by c-ELISA, considering it as gold standard test for seroprevalence study of Brucella infection.

\section{Introduction}

Bovine Brucellosis is a serious disease of livestock that has significant animal, public health and international trade consequences. Considering the damage done by the infection in animals such as death losses, decreased milk production, weight loss, infertility and lameness, this disease is a formidable threat to livestock. The fact that this disease can spread rapidly and be transmitted to humans makes it all the more serious. Brucella species are small, Gram-negative, non-motile, non-sporeforming, rod-shaped (cocco-bacilli) bacteria. Brucella abortus is the principal cause of Brucellosis in cattle. Once exposed, the likelihood of an animal becoming infected is variable, depending on age, pregnancy status, and other intrinsic factors of the animal, as well as the number of bacteria to which the animal was exposed (Radostitis et al., 2000). World Organisation for Animal Health (OIE) considers the disease as a threat of public health importance and a boundary for international trade of animals (OIE, 2004).

Specific antibodies against bacterial lipopolysaccharide and other antigens can be detected by the Standard Agglutination Test (SAT), Rose Bengal plate test, 2- 
mercaptoethanol (2-ME), Antihuman Globulin (Coombs), Indirect Enzyme Linked Immunosorbent Assay (ELISA) and Competitive Enzyme Linked Immunosorbent Assay. The Buffered Antigen Plate Agglutination test (BPAT) (Angus and Barton, 1984) and the Rose Bengal test (RBT) (Morgan et al., 1969) has been widely used. This test is considered as suitable screening tests for Brucellosis, followed by confirmatory testing. ELISA typically uses cytoplasmic proteins as antigens. It measures IgM, IgG and IgA with better sensitivity and specificity than the SAT in most recent comparative studies (Mantur et al., 2010). The specificity of the competitive enzyme immunoassay is very high; however, it is slightly less sensitive than the indirect enzyme immunoassay. This assay is not only an excellent confirmatory assay for the diagnosis of brucellosis in most mammalian species, but it is also capable of discriminating between Brucella infected animals and animals vaccinated with Brucella strain 19 in cattles.

\section{Materials and Methods}

\section{Study area}

Seroprevalence study of Brucella infection was carried out in cattle population of district Rewa (Madhya Pradesh), India. Rewa district situated in the north- eastern part of Madhya Pradesh. The climate of the district is humid subtropical with cold, misty winters, hot summer and humid monsoon season.

\section{Samples}

Total 50 serum samples of cattle from Laxman Bagh Gaushala, village- Paharkha and Silpara and from small organized farm of Rewa district were collected. Samples were stored at $-20^{\circ} \mathrm{C}$ until they were used. All the serum samples were tested for the presence of anti Brucella antibodies by using RBPT and c- ELISA kit.

\section{Rose Bengal plate test}

The standard technique suggested by Alton et $a l$. , (1975) was adopted in the present study to perform RBPT for cattle serum sample. The RBPT antigen was procured from Department of Veterinary Microbiology, College Of Veterinary Science and Animal Husbandry, Ludhiana, India. To perform the test antigen and serum were brought to the room temperature. Homogenous suspension of antigen was made by shaking the bottle containing antigen. Then, one drop $(0.03 \mathrm{ml})$ of serum sample and antigen was taken on the same slide using different micropipette and mixed thoroughly using a spreader. The slide was incubated with rotation for $4 \mathrm{~min}$ and immediately observed for results. A result was considered as positive when a noticeable agglutination was observed after 4 minutes.

\section{Competitive ELISA(c- ELISA)}

Competitive ELISA was performed using the SVANOVIR Brucella Ab c-ELISA kit using Brucella abortus smooth lipopolysaccharide (s-LPS) coated wells on microtiter plate. In order to perform the test reagents, samples and plate (s) were equilibrated to room temperature before use. $45 \mu 1$ of sample dilution buffer was dispensed into each well as per layout plan for serum sample, serum controls and conjugate control. After that $5 \mu \mathrm{l}$ of positive, weak positive and negative serum control was added into each of the appropriate well. $5 \mu 1$ of sample dilution buffer were added into conjugate control wells. Diluted test serum samples were dispensed at last. The sides of the plate were tapped to ensure even distribution of the antibody over the

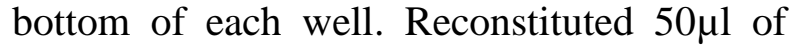
monoclonal antibody solution were dispensed into each wells, used for control and samples. 
Plate was covered with aluminium foil/lid and reagents mixed thoroughly for 5 minutes by tapping the sides of the plate. Plate was incubated at room temperature $\left(18-25^{\circ} \mathrm{C}\right)$ for 30 minutes. After incubation plates/ strips was washed four times with PBS-Tween buffer and tapped hard to remove all remains of fluid. After washing $100 \mu 1$ of conjugate solution was dispensed into each well. Again plate was covered with aluminium foil/lid and incubated at room temperature for 30 minutes.

After incubation plate/ strip was washed as above mentioned. After washing $100 \mu$ l of substrate solution added to each well and incubated at room temperature for 10 minutes.

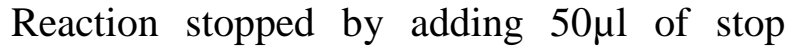
solution to each well and mixed thoroughly. Immediately after adding the stopping solution the plate was read in the ELISA plate reader at $450 \mathrm{~nm}$ wavelength.

Mean optical density (O.D.) value for each of the controls and samples were calculated. Percent Inhibition (PI) values for controls as well as samples were calculated as follows-

$\mathrm{PI}=100-\left(\mathrm{OD}_{\text {sample }} \mathrm{X} 100\right) / \mathrm{OD}_{\text {conjugate }}$ $\operatorname{control}(\mathrm{Cc})$

PI value for positive control, weak positive control and negative control were 80-100, 3070 , and (-10) to-15 respectively. Sample that gave more than $30 \%$ PI value were considered as positive, while below $30 \%$ were considered as negative. If sample showed PI value $30 \%$ then it was retested.

\section{Results and Discussion}

In cattle out of 50 samples tested, 21(42\%) were positive by RBPT, whereas $10(20 \%)$ were found to be positive by SVANOVIR cELISA kit (Table no. 1) (Figure 1). Further 6 $(28.57 \%)$ out of 21 RBPT positive serum samples were found to be positive, however $15(71.42 \%)$ were found negative by c-ELISA which showed positive result by RBPT. Out of total 10 samples found to be positive by SVANOVIR c-ELISA kit; four samples were such which were shown negative by RPBT. Considering the fact that by c-ELISA is highly specific test the overall positive cases detected is 20 percent.

Brucellosis is an important zoonosis and serological surveillance is essential for its control (Erdenebaatar et al., 2004). Although many countries have eradication programs for controlling brucellosis, economic losses can be heavy due to abortion and infertility and subsequent culling, so herds should be monitored for the presence of infection. Despite eradication programs, including vaccination, testing and slaughter, brucellosis remains a major zoonosis worldwide (WHO, 1986; Baek et al., 2003) and the disease has remained prevalent in many areas in the world.

Table.1 Seroprevalance of Brucella antibodies in cattle by RBPT and c- ELISA

\begin{tabular}{|c|c|c|c|}
\hline Study Area & $\begin{array}{c}\text { No.of serum samples } \\
\text { tested }\end{array}$ & RBPT positive & c- ELISA positive \\
& 50 & $21(42 \%)$ & samples \\
\hline $\begin{array}{c}\text { In and Around Rewa } \\
\text { District }\end{array}$ & $50 \%)$ \\
\hline
\end{tabular}


Fig.1 Microtiter plate showing the results of Competitive ELISA

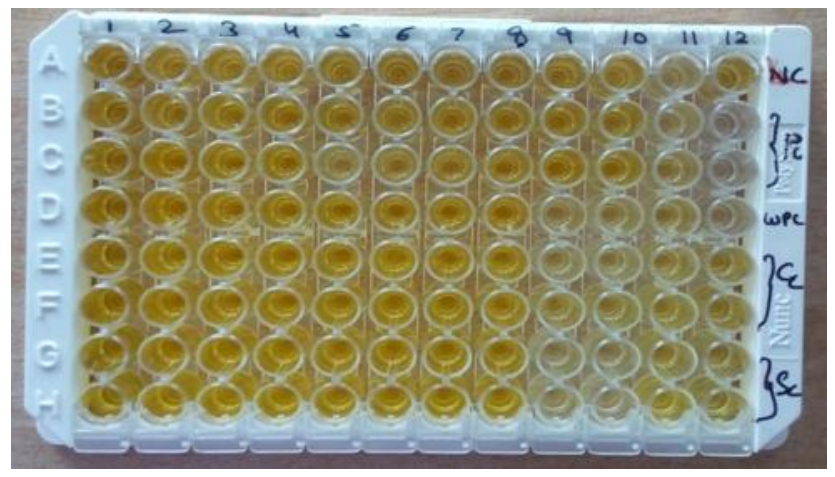

The results are in accordance with Mai et al., (2012) where they tested 4745 samples by RBPT out of which 1735 (36.6\%) were positive for Brucellosis. Out of 1735, 1137 $(65.5 \%)$ were confirmed to be seropositive for brucellosis upon further testing by c-ELISA. The competitive ELISA (c-ELISA) using monoclonal antibody (MAb) specific for one of the epitopes of the Brucella sp. OPS has been shown to have higher specificity but lower sensitivity than the I-ELISA (Macmillan et al., 1990; Munoz et al., 2005; Neilson et al., 1995; Stuck et al., 1999 and Weynants et al., 1997). This is accomplished by selecting a MAb that has higher affinity than cross-reacting antibody. However, it has been shown that the c-ELISA eliminates some but not all reactions due to cross-reacting bacteria (Munoz et al., 2005; Neilson, 2002).The c-ELISA is also capable of eliminating most reactions due to residual antibody produced in response to vaccination with S19. The choice of MAb and its unique specificity and affinity will have a distinct influence on the diagnostic performance characteristics of the assay. As with any MAb-based assay, the universal availability of the MAb or the hybridoma must also be considered with respect to international acceptance and widespread use. The results indicate that however the RBPT can be used as initial screening method for Brucella infection, the results should be confirmed by
c-ELISA. The overall positive cases detected by c-ELISA is 20 percent, revealing that there is significant prevalence of Brucella antibodies in cattle population in Rewa district, depicting the presence of Brucella infection in population and warranting the need for continued sero-surveillance of the disease posing a threat for disease condition.

\section{Acknowledgement}

Authors are thankful to Dr. P.N. Dwivedi, Professsor, Department of Veterinary Microbiology, Veterinary College, Ludhiana, GADVASU, and Dr. S.P. Shukla, Dean College of Veterinary Science and Animal Husbandry, Rewa, NDVSU, Jablapur for extending all the help required as and when needed.

\section{References}

Alton, G.G., Jones, L. M., and Pietz, D.E. 1975. Laboratory techniques in brucellosis. World Health Organisation, Geneva.

Angus, R., and Barton, C. 1984. The production and evaluation of a buffered plate antigen for use in the presumptive test for brucellosis. Dev. Biol. Std. 56: 349-58.

Baek, B. K., Lim, C.W., Rahman, M.S., Kim, C. H., Oluoch, A. and Kakoma, I. 2003. 
Brucella abortus infection in indigenous Korean dogs. Can J. Vet. Res. 67:312314.

Erdenebaatar, J., Bayarsaikhan, B., Yondondorji, A., Watarai, M., Shirahata, T., Jargalsaikhan, E., Kawamoto, K. and Makino, S. 2004. Epidemiological and serological survey of brucellosis in Mongolia by ELISA using sarcosine extracts. Microbiology and Immunology. 48: 571-577.

Macmillan, A. P., Greiser-wilke, I., Moennig, V. and Mathias, L. A. 1990. A competition enzyme immunoassay for brucellosis diagnosis. Dtsch Tierarztl. Wochenschr. 97:83-85.

Mai, M. H., Irons, C.P., Kabir, J. and Thompson, N. P. 2012. A large seroprevalance survey of brucellosis in cattle herds under diverse production systems in northern Nigeria. BMC Vet. Res. 8: 144.

Mantur, B., Parande, A., Amarnath, S., Patil, G., Walvekar, R., Desai, A., Parande, M., Shinde, R., Chandrashekar, M. and Patil, S. 2010. ELISA versus Conventional Methods of Diagnosing Endemic Brucellosis. Am. J. of Trop. Med. and Hyg. 83(2): $\quad 314-318$.

Morgan, W., MacKinnon, D., Lawson, J. and Cullen, G. 1969. The Rose Bengal plate agglutination test in the diagnosis of brucellosis. Vet. Rec. 85: 636-7.

Munoz, P., Marin, C., Monreal, D., Gonzales, D., Garin-bastuji, B., Diaz, R., MainarJaime, R., Moriyon, I. and Blasco, J. 2005. Efficacy of several serological tests and antigens for the diagnosis of bovine brucellosis in the presence of false positive serological results due to Yersinia enterocolitica O:9. Clin. Diagn. Lab Immunol.12: 141-151.

Nielsen, K., 2002. Diagnosis of brucellosis by serology. Vet. Microbiol.90: 447-459.

Nielsen, K., Kelly, L., Gall, D., Nicoletti, P. and Kelly, W. 1995. Improved competitive enzyme immunoassay for the diagnosis of bovine brucellosis. Vet. Immunol. Immunopathol. 46: 285-291.

Office International des Epizooties. 2004. In: International animal health code, 2.3.1. Acceded March 14.

Radostits, O.M., Gay, C.C., Blood, D.C. and Hinchcliffm, K.W. 2000. Veterinary Medicine: A textbook of the Diseases of Cattle, Sheep, Pigs, Goats and Horses. Harcourt Publishers Limited, London. Pp: 867-882.

Stuck, J.A., Perrett, L.L., Brew, S.D. and Macmillan, A.P. 1999. C-ELISA for bovine brucellosis suitable for testing poor quality samples. Vet. Record.145: 735-736.

Weynants, V., Gilson, D., Cloeckaert, A., Tibor, A., Denoel, P.A., Godfroid, F., Limet, J.N., and Letesson, J.J. 1997. Characterization of smoothlipopolysaccharide and $\mathrm{O}$ polysaccharides of sspecies by competition binding assays with monoclonal antibodies. Infect. Immun.65: 1939-1943.

WHO. 1986. Technical Report Series No. 740.6th report. Joint FAO/WHO Expert Committee on Brucellosis.

\section{How to cite this article:}

Vandana Gupta, Namrata Singh, Sanjay Kumar Shukla, Varsha Sharma, Anju Nayak, Joycee Jogi, Poonam Shakya and Ajay Rai. 2017. Seroprevalence Study of Brucella Infection in and around Rewa District. Int.J.Curr.Microbiol.App.Sci. 6(10): 4793-4797. doi: https://doi.org/10.20546/ijcmas.2017.610.446 